\title{
Environmental Management System and Performance in SMEs. Evidence from the Abruzzo Region
}

\author{
Danilo Boffa ${ }^{1}$
}

\begin{abstract}
The paper aims at investigating the potential effect on economic and financial performance caused by the adoption of an environmental management system ISO14001certification, by SMEs in Abruzzo region, which represent a significative case study due to the environmental capital that characterizes the whole region. From the Signaling Theory perspective, the adoption of such international environmental management system certification "signals" to the firm's stakeholders, the engagement in adopting a sustainable management system, contributing to reduce information asymmetry and consequently, positively influence economic and financial performance.

Considering a panel dataset of a total sample of 490 SMEs located in Abruzzo (observed from 2011 and 2019), constituted by 212 ISO14001 certified firms and a control group of 278 firms, selected comparing size, age and geographical location of the main group of analysis, the results show how economic and financial performance are positively related to the adoption of an environmental management system certification.
\end{abstract}

JEL classification numbers: O40, O44.

Keywords: ISO14001, SMEs, Environmental Management System, Signaling Theory, Abruzzo.

${ }^{1}$ University of Teramo, via R. Balzarini n. 1., 64100. Teramo, Italy. 


\section{Introduction}

The debate emerging from the literature regarding the nature and purpose of the entrepreneurial initiative, qualifies company as an economic-social institution and a socio-technical system (D'Amico, 2017). Companies' activities play a crucial role for corporate stakeholders and for the society in general (Corsi and Migliori, 2017), in different ways and intensities, in an ethical dimension that incorporates the economic and social dimensions, defining its role and mission (Ruisi, 2010; Di Carlo, 2017; Cortese and Cantino, 2020).

Regarding this issue, it is noted that the company unitary conception, in the classical meaning, starting from the business and economic studies conducted by Zappa, adequately defines the company as a system related to the ethical business dimension. As pointed out by Rusconi (2018) this ethical perspective has always permeated economic thoughts. From the Aristotelian Nicomachean Ethics to Friedman, who, although supporting the concept, according with the shareholder primacy and the profit maximisation, affirms that this duty it is subordinated to "compliance with the law and current customs" (Friedman, 1970).

Contrary to this vision, the introduction of issues related to business ethics in the corporate economic literature (Lewis, 1985), allowed to develop a research field that relegated business ethics with a limited role relating to the development of the capital system (Stark, 1993). Furthermore, the growing attention towards business activity has led to the development of Corporate Social Responsibility (CSR) concept, as a "social bond" deriving from the ethical dimension, which accompanies the complex corporate system activities.

In this perspective, the concept defined by "corporate social responsibility" has been implemented through different strategies, underlying the decision to adopt socially responsible behaviours, characterized as purely philanthropic choices, as compensation for socially irresponsible behaviour, or for the need to comply with rules and laws, perhaps not internally shared (Rusconi, 2018). The deepening reasons that underlie the CSR strategies in companies has been and is still being the subject of an important research stream (e.g., Graafland and Van de Ven, 2006; Graafland and Mazereeuw-Van der Duijn Schouten, 2012; Wang, Lam and Varshney, 2016; Mancini et al., 2016).

Developing issues related to the social responsibility, sustainable development and the growing request for the contribution to this shared mission in the public and private organizations, seems to led that the adoption of an ethical vision in the whole company system that is not compatible with the limitation of social responsibility to sporadic initiatives with a social impact, but it is the same systemic company vision (Paolone and D'Amico, 2017) that reasonably brings us closer to the concept of "shared value" creations, which anticipates international models (Freeman, 1984; Porter and Kramer, 2012), involving the essence and organisation purpose as a whole.

According with this perspective, corporate social responsibility leaves the role of an external limit towards company's economic and financial objective (Rusconi, 
2018), becoming a key factor for corporate success (Coda, 1989; 2010).

In addition, the management's motivations - including specifically opportunistic reasons - for the adoption of implicit and explicit strategies, of social responsibility in business management, promote competitive growth, facilitate the understanding and analysis of the competitive context in which they operate, as the relationship with the groups of corporate stakeholders, more interested in the sustainability organisations activities, especially for profit-making companies (Rusconi, 2018).

This debate emerging raises the fundamental question regarding how companies actually approach towards sustainable management in the complex set of activities and how this activity affects the economic and financial performance in the medium and long term. Particularly, despite the growing expectations of stakeholders, the literature highlights the specific medium-sized and micro enterprises behaviours in adopting sustainable and social responsibility approaches. Whilst the literature highlights some difficulties in adopting sustainability strategies related to the lack of managerial and financial resources (Shields and Shelleman, 2015, 2017; Kautonen et al., 2020; Wiesner, Chadee and Best, 2018), some SMEs characteristics seem to favour the implementation of social responsibility strategies, opposite to large companies, regarding the less formalization of decision-making, management and control processes and the flexibility and speed in adaptation to the reference context; to the greater ethical orientation and to the entrepreneur's value heritage; to the deepest link with the territorial environment in which SMEs operate (Del Baldo, 2009; Jamali, Zanhour and Keshishian, 2009; Mio, 2014; Tarquinio and Posadas, 2020).

Therefore, the analysis of the dynamics through small and medium-sized enterprises adopts sustainability strategies and how these strategies affect their economic and financial performance is the main aim of this research, to encourage, albeit only partially, the implementation and communication of sustainability initiatives and strategies in the small and medium-sized enterprises and micro-enterprises.

In particular, the research focuses on the emerging dynamics arising from the Region Abruzzo, strongly characterized by an economic environment characterized by micro and small and medium-sized enterprises (D'Amico, 1994). In addition, the choice to investigate this context is supported by some characteristics of this region, in particular:

- In the nineties, Abruzzo was characterized by an economic development that led it to the levels of the Central Italy regions, allowing to compete with European macro-regions. (European Commission, 1995). In 2019, Abruzzo was the southern region with the highest GDP per capita (equal to $85 \%$ of the European average value, on a par with Greece, Spain and Portugal) (Istat, 2020);

- The specific attention towards to environmental dimension. Abruzzo is characterized by a territory that has led it to be defined as the Green Europe Region, thanks to the extension of the National Parks and Protected Areas (3 national parks, 1 regional natural park, 52 protected reserves and natural reserves) which cover the $36.6 \%$ of the regional territory (Istat, Report BES 
2020). The environmental heritage safeguard and promotion represent a concrete regional's development objective.

- The lack of large industrial and urban districts and the almost exclusive presence of micro-enterprises and SMEs.

Therefore, the aim of this research is to investigate how the adoption of strategic and management approaches, oriented towards sustainability and corporate responsibility, affects the micro and SMEs economic and financial performance in Abruzzo. The relationship that we intend to investigate is intrinsic in the purpose of encouraging organizations to approach towards sustainable management in their business, analysing whether and to what extent this aspect can contribute to improve the economic performance.

In this research the relationship takes shape analysing how the integration of an ISO14001 certified environmental management system affects the company economic-financial performance, under the theoretical perspective of the signalling theory, which reflects the purpose of the environmental management system certification as a "signal" of the signaller's commitment towards sustainability and corporate social responsibility - the company - and the receivers - the stakeholders (Connelly, 2011; Taj, 2016; Todaro et al., 2020).

This paper is divided as follows. Section 2 presents and discusses the theoretical framework underlying the study and the advanced research hypotheses. Section 3 presents the sample, the variables used for the empirical analysis, the technique and the estimation models adopted. Section 4 highlights the descriptive and the results from the estimated models. Finally, section 5 discusses the analysis results, the main theoretical and practical managerial implications, with the limitations and the future research.

\section{Theoretical Framework and literature review}

The relationship between sustainability and the company's economic and financial performance is a widely topic analysed in the literature, underlying conflicting results regarding the sustainability dimensions (Epstein and Roy, 2003; Molteni, 2004; Ameer and Othman, 2012; Aggarwal, 2013; Weber, 2017; Cantele and Zardini, 2018; Alshehhi, Nobanee and Khare, 2018; Danso et al., 2019).

In particular, the debate relating the influence regarding the initiatives undertaken by companies to mediate the socio-environmental impact of their business activity appears controversial. Many studies found that these activities have a positive impact on economic and financial performance (Wheelen and Hunger, 2012; Ahamed, Almsafir and Al-Smadi, 2014; Kim and Kim, 2014; Maqbool and Zameer 2018; Platonova et al., 2018). Instead, other studies conducted, found a negative relationship between sustainability initiatives and the company's economic performance (Cordeiro and Sarkis, 1997; Wright and Ferris, 1997), while some research define this relationship undetectable due to the multiple variables involved (Griffin and Mahon, 1997; Kraft and Hage, 1990; McWilliams e Siegel, 2000).

Studies that support the positive relationship between the adoption of strategic 
approaches, aimed at sustainable development and economic and financial business performance, mainly refers to the promotion and the implementation of a management systems that consider the socio-economic impacts generated by the business activity.

In this perspective, the research gives great consideration especially to one aspect, i.e. the issue is to point out the adoption of sustainability practices to the business stakeholders with the aim of evaluating the business activity in its entirety and reducing informative asymmetries. (Connelly et al., 2011, Spence, 2002; Stiglitz, 2002). In that sense, it is alarming the growing concern of companies in adopting means of communication, information and reporting for sustainability that allow to communicate their commitment to the adoption of sustainable business management systems and models, including, the management system certifications. (Godemann and Michelsen, 2011; Newig et al., 2013; Reilly and Larya, 2018).

The company "need" to inform regarding the adoption of sustainable approaches can be framed under the perspective of the Signalling Theory (Boulding and Kirmani, 1993; Connelly et al., 2011). This theory is based on four key elements: signaller, signal, receiver, feedback. Under this perspective, in this research, the "Signalling Theory" helps us to understand the reasons behind the adoption of the ISO14001 environmental management system certification, typically used to point out the adoption of a standardized business management model.

ISO 14001 is a technical standard of the International Organization for Standardization on Environmental Management Systems (EMS) which determines the requirements that an organization, of any size, must comply in its environmental management system. ISO 14001 - revised in 2015 - presents a general discipline with the aim of certifying how the company management system is suitable for assessing and reducing the environmental impacts, and that it is oriented towards continuous improvement. Therefore, ISO 14001 can be defined as a process certification, and the requirements to obtain the certification are based on the 'Deming cycle': Plan-Do-Check-Act (PDCA) (Johnson, 2002).

Furthermore, the evaluation criteria of the company environmental management system are not determined according to a systematic and unambiguous framework, but they are defined on the basis of the industrial activity breakthrough. Therefore, the environmental management system adequacy assessment will be preceded from a context analysis, highlighting the needs and expectations of stakeholders and the main impacts generated.

This procedure is based on one of the fundamental requisites for obtaining the ISO14001 certification: green procurement. Organizations must define and apply environmental criteria to products and services purchases that support production or trade. The adaptation to this type of international standards, highlights common benefits for all company typological classes, including: the internal performance improvement and efficiency (cost reduction, productivity growth, profit growth, internal process improvement, workers motivation improvement), the company public image and the quality brand perception for the customer, the relationship improvement regarding socio-economic context and with the institutions (Tarí, 
Molina-Azorín and Heras, 2012).

In particular, the ratio underlying the decision to adopt the standard that certifies the company management system environmental protection ISO14001 is linked to the national and international context in which the company operates. Although, the annual certification and management fee is particularly high, it should be noted that the first reason that pushes companies to certify is the economic performance increase, since it becomes the means - signal - through to signal the adequacy of their environmental management system to certain standards, thus reducing information asymmetries, and the cost of alternatively externally reporting (Morrow and Rondinelli, 2002; Babakri, Bennett and Franchetti, 2003; Heras-Saizarbitoria, Molina-Azorín and Dick, 2011).

This is particularly relevant regarding the small and medium-sized enterprises (Johnstone, 2020). The scarcity of economic, financial and human resources involves the lack of means and skills to adequately inform stakeholders regarding the initiatives aimed at mitigating the environmental impact through the information disclosure and specific reports and documents (including, for example: Sustainability Report, Social Report, Integrated Report) (Shields and Shelleman, 2017).

According to the Signalling Theory framework, this research aims to investigate the following research hypothesis:

H1: The adoption of an ISO14001 certified environmental management system positively influences the SMEs economic performance in Abruzzo.

\section{Methodology}

\subsection{Analysis sample and data source}

In order to empirically verify the research hypothesis, a panel data of 212 ISO14001 certified micro, small and medium-sized enterprises from Abruzzo (identified on the basis of the database of companies available by Accredia - the Italian accreditation body ${ }^{2}$ ), was analysed, extracted from AIDA BvD database, an Italian subset of ORBIS database, that include historical data relating to economic, financial, biographical and commodity elements of approximately 700,000 active Italian companies. In particular, the financial information is provided by Honyvem, which acquires and re-elaborates the financial statements filed in the Italian Chambers of Commerce. The data refer from 2011 to 2019. In addition, a control group of 278 non-ISO14001 certified companies was extracted from the Aida database to rationally determine the impact of this certification on the company's economic and financial performance. The control group was selected relating to the geographical location, size and the company age. Based on the list of ISO 14001

\footnotetext{
2 Accredia is the Single Accreditation authority designated by the Italian government for the competence verification and attestation, independence and impartiality of the bodies and laboratories that verify the compliance of goods and services with the standards. It carries out its function according to the EC Regulation 765/2008 and the ISO / IEC 17011 international standard.
} 
certified companies, a matrix was generated to outline the company geographic, dimensional, and age-related determinants. Subsequently, the data of non-certified companies were randomly collected from AIDA based on the defined criteria. Due to these considerations, the final sample is composed by 490 companies. Tables 1 and 2 show the matrices of the certified companies and the total sample of the companies considered, and it is possible to compare the percentages relating to the characteristics of the sample considered.

Table 1: ISO14001 certified enterprises Sample matrices

\begin{tabular}{|c|c|c|c|c|}
\hline \multicolumn{5}{|c|}{ CHIETI } \\
\hline \multirow[b]{2}{*}{ AGE } & \multicolumn{3}{|c|}{ SIZE } & \multirow[b]{2}{*}{ Total } \\
\hline & $\begin{array}{c}0-9 \\
\text { Employees }\end{array}$ & $\begin{array}{c}10-49 \\
\text { Employees }\end{array}$ & $\begin{array}{c}50+ \\
\text { Employees }\end{array}$ & \\
\hline $0-19$ years & $9(4,24 \%)$ & $17(8 \%)$ & $5(2,35 \%)$ & $31(14,6 \%)$ \\
\hline $20-29$ years & $2(0,94 \%)$ & $15(7,07 \%)$ & $10(4,71 \%)$ & $27(12,73 \%)$ \\
\hline $30+$ years & $1(0,47 \%)$ & $17(8 \%)$ & $13(6,13 \%)$ & $31(14,62 \%)$ \\
\hline Total & $12(5,66 \%)$ & $49(23,11 \%)$ & $28(13,20 \%)$ & $89(41,98 \%)$ \\
\hline \multicolumn{5}{|c|}{ L'AQUILA } \\
\hline & \multicolumn{3}{|c|}{ SIZE } & \\
\hline AGE & $\begin{array}{c}0-9 \\
\text { Employees }\end{array}$ & $\begin{array}{c}10-49 \\
\text { Employees }\end{array}$ & $\begin{array}{c}\mathbf{5 0}+ \\
\text { Employees }\end{array}$ & Total \\
\hline $0-19$ years & $3(1,4 \%)$ & $7(3,3 \%)$ & $3(1,4 \%)$ & $13(6,13 \%)$ \\
\hline 20-29 years & 0 & $4(1,8 \%)$ & $3(1,4 \%)$ & $7(3,3 \%)$ \\
\hline $30+$ years & $1(0,47 \%)$ & $7(3,3 \%)$ & $4(1,8 \%)$ & $12(5,66 \%)$ \\
\hline Total & $4(1,8 \%)$ & $18(8,49 \%)$ & $10(4,71 \%)$ & $32(15,09 \%)$ \\
\hline \multicolumn{5}{|c|}{ PESCARA } \\
\hline & \multicolumn{3}{|c|}{ SIZE } & \\
\hline AGE & $\begin{array}{c}\text { 0-9 } \\
\text { Employees }\end{array}$ & $\begin{array}{c}10-49 \\
\text { Employees }\end{array}$ & $\begin{array}{c}\mathbf{5 0 +} \\
\text { Employees }\end{array}$ & Total \\
\hline $0-19$ years & $3(1,4 \%)$ & $6(2,83 \%)$ & $4(1,8 \%)$ & $13(6,13 \%)$ \\
\hline $20-29$ years & 0 & $11(5,18 \%)$ & $4(1,8 \%)$ & $15(7,07 \%)$ \\
\hline $30+$ years & $2(0,47 \%)$ & $5(2,35 \%)$ & $6(2,83 \%)$ & $13(6,13 \%)$ \\
\hline Total & $5(2,35 \%)$ & $22(10,37 \%)$ & $10(4,71 \%)$ & $41(19,33 \%)$ \\
\hline \multicolumn{5}{|c|}{ TERAMO } \\
\hline & \multicolumn{3}{|c|}{ SIZE } & \\
\hline AGE & $\begin{array}{c}0-9 \\
\text { Employees }\end{array}$ & $\begin{array}{c}10-49 \\
\text { Employees }\end{array}$ & $\begin{array}{c}\mathbf{5 0 +} \\
\text { Employees }\end{array}$ & Total \\
\hline 0-19 years & $2(0,47 \%)$ & $14(6,60 \%)$ & $5(2,35 \%)$ & $21(9.90 \%)$ \\
\hline 20-29 years & $3(1,4 \%)$ & $9(4,24 \%)$ & $5(2,35 \%)$ & $17(8 \%)$ \\
\hline $30+$ years & $2(0,47 \%)$ & $4(1,8 \%)$ & $6(2,83 \%)$ & $12(5,66 \%)$ \\
\hline Total & $7(3,3 \%)$ & $27(12,73 \%)$ & $16(7,54 \%)$ & $50(23,58 \%)$ \\
\hline
\end{tabular}

Source: Author's elaboration. 
Table 2: Total sample analysis matrices

\begin{tabular}{|c|c|c|c|c|}
\hline \multicolumn{5}{|c|}{ CHIETI } \\
\hline \multirow[b]{2}{*}{ AGE } & \multicolumn{3}{|c|}{ SIZE } & \multirow[b]{2}{*}{ Total } \\
\hline & $\begin{array}{c}0-9 \\
\text { Employees }\end{array}$ & $\begin{array}{c}10-49 \\
\text { Employees }\end{array}$ & $\begin{array}{c}50+ \\
\text { Employees }\end{array}$ & \\
\hline $0-19$ years & $21(4,28 \%)$ & $39(7,95 \%)$ & $11(2,24 \%)$ & $71(14,48 \%)$ \\
\hline 20-29 years & $5(1,02 \%)$ & $35(7,14 \%)$ & $23(4,69 \%)$ & $63(12,85 \%)$ \\
\hline $30+$ years & $4(0,81 \%)$ & $39(7,95 \%)$ & $29(5,91 \%)$ & $72(14,69 \%)$ \\
\hline Total & $30(6,12 \%)$ & $113(23,06 \%)$ & $63(12,85 \%)$ & $206(42,04 \%)$ \\
\hline \multicolumn{5}{|c|}{ L'AQUILA } \\
\hline & \multicolumn{3}{|c|}{ SIZE } & \\
\hline AGE & $\begin{array}{c}0-9 \\
\text { Employees } \\
\end{array}$ & $\begin{array}{c}10-49 \\
\text { Employees }\end{array}$ & $\begin{array}{c}\mathbf{5 0}+ \\
\text { Employees }\end{array}$ & Total \\
\hline 0-19 years & $7(1,42 \%)$ & $16(3,26 \%)$ & $7(1,42 \%)$ & $30(6,12 \%)$ \\
\hline 20-29 years & 0 & $9(1,83 \%)$ & $7(1,42 \%)$ & $16(3,26 \%)$ \\
\hline $30+$ years & $3(0,61 \%)$ & $16(17,7 \%)$ & $9(1,83 \%)$ & $28(5,71 \%)$ \\
\hline Total & $10(2,04 \%)$ & $41(8,36 \%)$ & $23(4,69 \%)$ & $74(15,10 \%)$ \\
\hline \multicolumn{5}{|c|}{ PESCARA } \\
\hline & \multicolumn{3}{|c|}{ SIZE } & \\
\hline AGE & $\begin{array}{c}0-9 \\
\text { Employees }\end{array}$ & $\begin{array}{c}10-49 \\
\text { Employees }\end{array}$ & $\begin{array}{c}\mathbf{5 0 +} \\
\text { Employees } \\
\end{array}$ & Total \\
\hline $0-19$ years & $7(1,4 \%)$ & $14(2,85 \%)$ & $9(1,83 \%)$ & $30(6,12 \%)$ \\
\hline 20-29 years & 0 & $25(5,10 \%)$ & $9(1,83 \%)$ & $34(6,93 \%)$ \\
\hline $30+$ years & $5(2,35 \%)$ & $12(2,44 \%)$ & $14(2,85 \%)$ & $31(6,32 \%)$ \\
\hline Total & $12(2,44 \%)$ & $51(10,37 \%)$ & $32(6,53 \%)$ & $95(19,38 \%)$ \\
\hline \multicolumn{5}{|c|}{ TERAMO } \\
\hline & \multicolumn{3}{|c|}{ SIZE } & \\
\hline AGE & $\begin{array}{c}\text { 0-9 } \\
\text { Employees }\end{array}$ & $\begin{array}{c}10-49 \\
\text { Employees }\end{array}$ & $\begin{array}{c}50+ \\
\text { Employees }\end{array}$ & Total \\
\hline $0-19$ years & $5(2,35 \%)$ & $32(6,53 \%)$ & $11(2,24 \%)$ & $48(9.79 \%)$ \\
\hline $20-29$ years & $7(1,4 \%)$ & $21(4,28 \%)$ & $11(2,24 \%)$ & $39(7,95 \%)$ \\
\hline $30+$ years & $5(2,35 \%)$ & $12(2,44 \%)$ & $14(2,85 \%)$ & $28(5,71 \%)$ \\
\hline Total & $7(3,3 \%)$ & $62(12,65 \%)$ & $36(7,34 \%)$ & $115(23,46 \%)$ \\
\hline
\end{tabular}

Source: Author's elaboration.

\subsection{Variables Description}

\subsubsection{Dependent variable}

In order to highlight the emerging relationship between the company economic results analysed and the adoption of a certified environmental management system, the ROA (Return on Assets) profitability index was used as a proxy of the company 
economic performance. Regarding the economic and financial results, the literature identifies a set of variables that can be described in 2 macro-groups: market-based variables and accounting based variables (Garcia-Castro, Ariño and Canela, 2010; Lassala, Apetrei and Sapena, 2017; Alshehhi, Nobanee and Khare, 2018). The accounting variables includes the ROA index, used in this research.

Although some limitations have been highlighted for both methodologies, it emerges that the accounting indicators are in any case considered more suitable than the market-based ones to assess company performance. (Wu, 2006). Furthermore, although the company behaviour can be explained using market-based indexes, accounting data shows what really happens in the company (López, Garcia and Rodriguez, 2007), while the market-based variables reflect the profitability expectations, including additional macroeconomic factors that affect these measures.

The Return on Assets (ROA) represents the profitability of assets utilisation and measures managerial efficiency. According to this perspective, it emerges that ROA ratio is, a necessary condition for achieving the profitability outcome. Furthermore, ROA is one of the most financial-used measure (Alshehhi et al,2018) to understand the relationship between corporate sustainability practices and financial performance.

Therefore, the use of the ROA profitability index - defined by the ratio of operating profit to total assets - appears consistent with the purposes of this research.

\subsubsection{Independent Variable}

Referring the independent variable used to estimate the model, we consider the adoption of the ISO14001 environmental management system certification, which, as anticipated in the theoretical framework in section 2, determines the adoption of a company management and operations system oriented towards sustainable development. Hence, a dummy variable has been constructed and assumes a value 1 if the company is ISO14001 certified and 0 otherwise.

\subsubsection{Control Variables}

In order to verify the presence of functional effects on the dependent variable, a set of control variables was introduced in the model. Specifically, we used first the company size, as the natural logarithm of the number of employees in 2019 (Size). Secondly, we introduce a variable that express the company age (Age) calculated as the natural logarithm of age up to 31/12/2019.

Thirdly, an indicator was included to describe the corporate financial structure, through the variable Debt/Equity, measured as the ratio between total corporate debt and equity (D/E). As a further control variable of the hypothesized relationship, the geographical variable - considering the Abruzzo provinces in which the company is located (Teramo, L'Aquila, Chieti, Pescara) - and the temporal variable (Years) were considered - to verify the effects of the variables in the period considered (2011-2019). 


\subsection{Analytical investigation approach}

The analysis of the potential effects exerted by the adoption of a certified environmental management system on the company's economic and financial performance was conducted according to an empirical approach divided into two stages. In the first, descriptive analysis of the selected sample was performed and, a specific analysis was conducted to exclude the presence of multicollinearity among the independent variables. Specifically, a VIF - Variance Inflation Factor analysis and a Pearson's bivariate correlation analysis were conducted to verify the absence of high and significant correlation coefficient between the independent variables. Furthermore, with the aim of empirically validating the research hypothesis, a GLS - Generalized Least Square Regression model was developed, particularly suitable to estimate the linear relationships between variables in a panel dataset.

Regarding the models used for the study, the function that expresses the relationship between the company economic and financial performance and the adoption of a certified environmental management system can be described as follows:

$R O A_{i t}=\beta_{1}{\text { ISO } 14001_{i t}}+\beta_{2}$ CONTROL $_{i t}+\varepsilon_{i t}$

where CONTROL represents the vector of control variables and $\varepsilon_{i t}$ the company's error term $i$ at the time $t$.

\section{Results}

\subsection{Descriptive statistics}

Table 3 shows the descriptive statistics, separately computed for ISO14001 and non-ISO14001 certified companies. It should be noted that the companies that adopt an ISO14001 certified environmental management system show, on average, a higher profitability with a similar variability than non-certified companies. Furthermore, certified companies are, on average, larger than non-certified companies, with a lower ratio between corporate liabilities and equity capital. 
Table 3: Descriptive statistics separately calculated for ISO14001 certified and noncertified companies

\begin{tabular}{|c|c|c|c|c|c|}
\hline \multicolumn{7}{|c|}{ ISO14001 = 0 } \\
\hline Variables & Obs & Mean & SD & Min & Max \\
\hline Age & 2,502 & 24.46043 & 10.92886 & 9 & 58 \\
\hline Employees & 2,502 & 24.46043 & 47.87702 & 2 & 225 \\
\hline Assets & 2,417 & 7954.703 & 17171.54 & 0.816 & 276223.3 \\
\hline ROA & 2,417 & 4.727571 & 13.139 & -329.17 & 65.67 \\
\hline Debt/Equity & 1,912 & 2.153651 & 7.775759 & -82.86 & 161.79 \\
\hline \multicolumn{7}{|c|}{ ISO14001 = 1 } \\
\hline Variables & Obs & Mean & SD & Min & Max \\
\hline Age & 1,908 & 24.71226 & 10.26331 & 9 & 59 \\
\hline Employees & 1,908 & 50.15094 & 53.36991 & 2 & 244 \\
\hline Assets & 1,907 & 14756.98 & 27235.3 & 14.872 & 308646.2 \\
\hline ROA & 1,907 & 6.067672 & 9.124103 & -55.88 & 67.28 \\
\hline Debt/Equity & 1,723 & 1.751741 & 6.618009 & -11.69 & 156.05 \\
\hline
\end{tabular}

Source: Author's elaboration

Table 4 shows the values from the VIF analysis computed for the independent variable and the control variables analysed. The results show that the VIF coefficients, for each variable and the mean value, are lower than the cut off value of 4 (VIF <4), as well as the values of 1 / VIF are higher than 0.2 , traditionally considered as limit values to verify the presence of multicollinearity (Hair et al., 2010).

Table 4: VIF analysis results - Variable Inflation Factor

\begin{tabular}{|c|c|c|}
\hline Variables & VIF & 1/VIF \\
\hline Chieti & 2.26 & 0.4430 \\
\hline Teramo & 2.00 & 0.4999 \\
\hline Pescara & 1.91 & 0.5228 \\
\hline AGE & 1.07 & 0.9303 \\
\hline Employees & 1.06 & 0.9435 \\
\hline D/E & 1.01 & 0.9923 \\
\hline Mean VIF & 1.55 & \\
\hline
\end{tabular}

Source: Author's elaboration

Table 5 shows the Pearson's bivariate correlation matrix: the absence of high and significant correlation between the predictors and the control variables suggests that multicollinearity doesn't represent a critical issue. Therefore, it is possible to conduct the empirical analysis according to the models and the estimation method defined in the previous section. 
Table 5: Pearson's bivariate correlation matrix

\begin{tabular}{|c|c|l|l|l|l|l|l|l|l|l|}
\hline & Variables & $\mathbf{1}$ & $\mathbf{2}$ & $\mathbf{3}$ & $\mathbf{4}$ & $\mathbf{5}$ & $\mathbf{6}$ & $\mathbf{7}$ & $\mathbf{8}$ & $\mathbf{9}$ \\
\hline 1 & ROA & 1.0000 & & & & & & & & \\
\hline 2 & ISO14001 & $.0576^{*}$ & 1.0000 & & & & & & & \\
\hline 3 & Age & $-.0820^{*}$ & .0263 & 1.0000 & & & & & & \\
\hline 4 & Employees & .0190 & $.1034^{*}$ & $.2519^{*}$ & 1.0000 & & & & & \\
\hline 5 & Teramo & .0282 & .0024 & $-.0516^{*}$ & .0173 & 1.0000 & & & & \\
\hline 6 & Chieti & -.0181 & -.0011 & $.0471^{*}$ & $-.0373^{*}$ & $-.4716^{*}$ & 1.0000 & & & \\
\hline 7 & L'Aquila & -.0103 & -.0002 & $-.0357^{*}$ & .0150 & $-.2336^{*}$ &.$- .3592^{*}$ & 1.0000 & & \\
\hline 8 & Pescara & .0015 & -.0011 & .0288 & .0144 & $-.2716^{*}$ &.$- .4177^{*}$ & $-.2068^{*}$ & 1.0000 & \\
\hline 9 & D/E & $-.0400^{*}$ & -.0277 & $-.0667^{*}$ & $-.0539^{*}$ & -.0147 & .0100 & $.0352^{*}$ & -.0275 & 1.0000 \\
\hline
\end{tabular}

\subsection{Estimation of regression models}

Table 6 shows the results of the regression model. The model was completed following the stepwise method: the control variables estimation is shown in column (I), while the estimation of the main effects is included in column (II).

These results show a positive and significant relationship between the adoption of an environmental management system certification (ISO14001) and the company's economic and financial results, measured with the ROA value (Column II, 1.3646, p> 0.05) which allows us to support the research hypothesis H1. Furthermore, it is possible to verify that, for the control variables, there are no significant variations in the values and in the coefficients' significance, demonstrating how the choice of these variables are functional to correctly define the estimated model. 
Table 6: Results of the estimated GLS regression models

\begin{tabular}{|c|c|c|}
\hline & (I) & (II) \\
\hline ISO14001 & & $1.3646 * * \quad(0.6835)$ \\
\hline \multicolumn{3}{|c|}{ Control Variables } \\
\hline Age & $-2.2214 * * \quad(0.7803)$ & $\begin{array}{c}-2.2159 * * \\
(0.7781)\end{array}$ \\
\hline Employees & $0.5311 * \quad(0.3162)$ & $-0.4740 \quad(0.3166)$ \\
\hline Teramo & $-0.6280 \quad(1.0367)$ & $-0.7340 \quad(1.0337)$ \\
\hline Chieti & $-0.5640 \quad(0.9297)$ & $-0.6006 \quad(0.9272)$ \\
\hline L'Aquila & $-1.1131 \quad(1.1682)$ & $-1.1180 \quad(1.1648)$ \\
\hline Pescara & (omitted) & (omitted) \\
\hline $\mathrm{D} / \mathrm{E}$ & $-0.3416 \quad(0.0167)$ & $-0.3362 \quad(0.2829)$ \\
\hline \multicolumn{3}{|c|}{ Year } \\
\hline 2012 & $0.8724 \quad(0.6908)$ & $0.8721 \quad(0.6908)$ \\
\hline 2013 & $1.2748 * \quad(0.6909)$ & $1.2719 * \quad(0.6915)$ \\
\hline 2014 & $0.6702 \quad(0.7048)$ & $0.6679 \quad(0.7048)$ \\
\hline 2015 & $1.1568 * \quad(0.7015)$ & $1.1552 * \quad(0.7015)$ \\
\hline 2016 & $0.5519 \quad(0.7036)$ & $0.5496 \quad(0.7036)$ \\
\hline 2017 & $1.0055 \quad(07024)$ & $1.0090 \quad(0.7023)$ \\
\hline 2018 & $0.7649 \quad(0.6969)$ & $0.7675 \quad(0.6969)$ \\
\hline 2019 & $0.07352 \quad(0.6968)$ & $0.7957 \quad(0.6967)$ \\
\hline N. of observations & 3635 & 3635 \\
\hline N. of groups & 484 & 484 \\
\hline Wald chi2 (25) & 18.23 & 22.29 \\
\hline Overall R2 & 0.1963 & 0.1005 \\
\hline
\end{tabular}

Note: Robust standard errors are shown in parentheses.

$* \mathrm{p}<0,10 . \quad * * \mathrm{p}<0,05 . * * * \mathrm{p}<0,001$.

Source: author's elaboration 


\section{Conclusion}

The results from the empirical analysis allow us to state that the implementation of an environmental management system, to obtain ISO14001 certification, with the aim to assess and reduce environmental impacts and to plan sustainability and corporate social responsibility strategies, positively influence the economic and financial performance of Abruzzo SMEs and allow us to affirmatively answer the research question and to confirm the relationship hypothesized in paragraph 2 . These results are part of the research line that supports the adoption of management approaches and models towards sustainable development and, therefore, allow to mitigate social and environmental impacts of the business activity contributing to the economic performance improvement. (Wheelen e Hunger, 2012; Ahamed, Almsafir e Al-Smadi, 2014; Kim e Kim, 2014; Maqbool e Zameer, 2018; Platonova et al., 2018).

Under the Signalling Theory perspective, the research contributes to the theoretical development, showing how the management system environmental ISO14001 certification is suitable as a signalling tool for the orientation towards the sustainable development of small and medium-sized enterprises in Abruzzo, noting a positive influence relating to corporate stakeholders, signal receivers, reducing information asymmetries and the related costs. Hence, it contributes to the company results improvement. The Signalling Theory, used as a theoretical framework for this research, highlights that the company's reporting orientation towards sustainable development, through useful tools to communicates the specific characteristics of the environmental management system - such as ISO14001 certification - both functional and not only for the specific purpose - or to demonstrate compliance with an international standard for the promotion of sustainable models -, but to contribute to the improvement of economic results and company profitability.

From a practical point of view, this research offers some managerial implications. It helps to show that the adoption of an environmental management system, with its reporting process and the alignment with an international standard, contributes to the reduction of the social and environmental impact and to improve the economic performance, with particular reference to SMEs, that need to implement proper communication tools for their commitment in sustainability initiatives, facing the lack of economic resources and specific skills, widely discussed in the literature. 


\section{References}

[1] Aggarwal, P. (2013). Impact of sustainability performance of company on its financial performance: A study of listed Indian companies. Global Journal of Management and Business Research (C: Finance) Vol, 13.

[2] Ahamed, W. S. W., Almsafir, M. K., and Al-Smadi, A. W. (2014). Does corporate social responsibility lead to improve in firm financial performance? Evidence from Malaysia. International Journal of Economics and Finance, 6(3), 126-138.

[3] Alshehhi, A., Nobanee, H., and Khare, N. (2018). The impact of sustainability practices on corporate financial performance: Literature trends and future research potential. Sustainability, 10(2), 494.

[4] Ameer, R., and Othman, R. (2012). Sustainability practices and corporate financial performance: A study based on the top global corporations. Journal of business ethics, 108(1), 61-79.

[5] Babakri, K. A., Bennett, R. A., and Franchetti, M. (2003). Critical factors for implementing ISO 14001 standard in United States industrial companies. Journal of cleaner production, 11(7), 749-752.

[6] Boulding, W., and Kirmani, A. (1993). A consumer-side experimental examination of signaling theory: do consumers perceive warranties as signals of quality?. Journal of consumer research, 20(1), 111-123.

[7] Cantele, S., and Zardini, A. (2018). Is sustainability a competitive advantage for small businesses? An empirical analysis of possible mediators in the sustainability-financial performance relationship. Journal of Cleaner Production, 182, 166-176.

[8] Coda, V. (1989). Etica e impresa: il valore dello sviluppo. Rivista dei dottori commercialisti, (5), 789-800.

[9] Coda, V. (2010). Entrepreneurial Values and Strategic Management. Essays in Management Theory. Basingstoke: Palgrave, Macmillan.

[10] Commission of the European Communities. Directorate-General for Regional Policy and Cohesion. (1995). Development Prospects of the Central Mediterranean Regions (Mezzogiorno-Greece). Office for Official Publications of the European Communities.

[11] Connelly, B. L., Certo, S. T., Ireland, R. D., and Reutzel, C. R. (2011). Signaling theory: A review and assessment. Journal of management, 37(1), 3967.

[12] Cordeiro, J. J., and Sarkis, J. (1997). Environmental proactivism and firm performance: evidence from security analyst earnings forecasts. Business strategy and the environment, 6(2), 104-114.

[13] Corsi, C., and Migliori, S. (2017). Le pmi italiane: governance, internazionalizzazione e struttura finanziaria. Franco Angeli, Milano.

[14] Cortese, D., and Cantino, V. (2020). Finalità dell'impresa: equilibrio tra sostanza, interpretazioni e condizioni mutevoli. 
[15] D'Amico, L. (2017). L'evoluzione degli studi sull'economia d'azienda: brevi considerazioni sull'inquadramento della disciplina, in "I principi e i modelli de l'Economia Aziendale” di G. Paolone, L. D’Amico (a cura di), Giappichelli Editore, Torino.

[16] D'Amico, L. (1994). Le strutture imprenditoriali della Regione Abruzzo, Atti della Regione Abruzzo, Pescara.

[17] Danso, A., Adomako, S., Amankwah-Amoah, J., Owusu-Agyei, S., and Konadu, R. (2019). Environmental sustainability orientation, competitive strategy and financial performance. Business Strategy and the Environment, 28(5), 885-895.

[18] Del Baldo, M. (2009). Corporate social responsability e corporate governance: quale nesso nelle PMI?. Piccola impresa: Small Business, (3), 61.

[19] Di Carlo, E. (2017). Interesse primario dell'azienda come principio-guida e bene comune. Giappichelli Editore, Torino.

[20] Epstein, M. J., and Roy, M. J. (2003). Making the business case for sustainability: linking social and environmental actions to financial performance. Journal of Corporate Citizenship, (9), 79-96.

[21] Freeman, R. E. (1984). Strategic management: A stakeholder approach. Pitman, Boston.

[22] Friedman, M. (1970). A theoretical framework for monetary analysis. journal of Political Economy, 78(2), 193-238.

[23] Garcia-Castro, R., Ariño, M. A., and Canela, M. A. (2010). Does social performance really lead to financial performance? Accounting for endogeneity. Journal of Business Ethics, 92(1), 107-126.

[24] Godemann, J., and Michelsen, G. (2011). Sustainability communication-an introduction. In Sustainability communication (pp. 3-11). Springer, Dordrecht.

[25] Graafland, J., and Mazereeuw-Van der Duijn Schouten, C. (2012). Motives for corporate social responsibility. De Economist, 160(4), 377-396.

[26] Graafland, J., and Van de Ven, B. (2006). Strategic and moral motivation for corporate social responsibility. Journal of Corporate Citizenship, (22), 111123.

[27] Griffin, J. J., and Mahon, J. F. (1997). The corporate social performance and corporate financial performance debate: Twenty-five years of incomparable research. Business \& society, 36(1), 5-31.

[28] Hair, J., Black, W., Babin, B., Anderson, R., and Tatham, R. (2010). Multivariate data analysis. Pearson Education Inc, New Jersey.

[29] Heras-Saizarbitoria, I., Molina-Azorín, J. F., \& Dick, G. P. (2011). ISO 14001 certification and financial performance: selection-effect versus treatmenteffect. Journal of Cleaner Production, 19(1), 1-12.

[30] Jamali, D., Zanhour, M., and Keshishian, T. (2009). Peculiar strengths and relational attributes of SMEs in the context of CSR. Journal of business Ethics, 87(3), 355-377.

[31] Johnson, C. N. (2002). The benefits fo PDCA. Quality Progress, 35(5), 120. 
[32] Johnstone, L. (2020). The construction of environmental performance in ISO 14001-certified SMEs. Journal of Cleaner Production, 263, 121559.

[33] Kautonen, T., Schillebeeckx, S. J., Gartner, J., Hakala, H., Salmela-Aro, K., and Snellman, K. (2020). The dark side of sustainability orientation for SME performance. Journal of Business Venturing Insights, 14, e00198.

[34] Kim, M., and Kim, Y. (2014). Corporate social responsibility and shareholder value of restaurant firms. International Journal of Hospitality Management, 40, 120-129.

[35] Kraft, K. L., and Hage, J. (1990). Strategy, social responsibility and implementation. Journal of Business Ethics, 9(1), 11-19.

[36] Lassala, C., Apetrei, A., and Sapena, J. (2017). Sustainability matter and financial performance of companies. Sustainability, 9(9), 1498.

[37] Lewis, P. V. (1985). Defining 'business ethics': Like nailing jello to a wall. Journal of Business ethics, 4(5), 377-383.

[38] López, M. V., Garcia, A., and Rodriguez, L. (2007). Sustainable development and corporate performance: A study based on the Dow Jones sustainability index. Journal of business ethics, 75(3), 285-300.

[39] Mancini, D., Lamboglia, R., Garzella, S., and Fiorentino, R. (2016). Strategie di sostenibilità: dalle motivazioni ai sistemi di misurazione della performance. Management Control, 2, 116-142.

[40] Maqbool, S., and Zameer, M. N. (2018). Corporate social responsibility and financial performance: An empirical analysis of Indian banks. Future Business Journal, 4(1), 84-93.

[41] McWilliams, A., and Siegel, D. (2000). Corporate social responsibility and financial performance: correlation or misspecification?. Strategic management journal, 21(5), 603-609.

[42] Mio, C. (2014). Imprese artigiane e corporate social responsibility, in «Quaderni di ricerca sull'artigianato», 2, pp. 227-252.

[43] Molteni, M. (2004). Responsabilità sociale e performance d'impresa. Per una sintesi socio-competitiva. Vita e pensiero, Milano.

[44] Morrow, D., and Rondinelli, D. (2002). Adopting corporate environmental management systems: Motivations and results of ISO 14001 and EMAS certification. European management journal, 20(2), 159-171.

[45] Newig, J., Schulz, D., Fischer, D., Hetze, K., Laws, N., Lüdecke, G., and Rieckmann, M. (2013). Communication regarding sustainability: Conceptual perspectives and exploration of societal subsystems. Sustainability, 5(7), 2976-2990.

[46] Paolone, G., and D'Amico, L. (2017). I principi ei modelli de l'Economia Aziendale. Giappichelli Editore, Torino.

[47] Platonova, E., Asutay, M., Dixon, R., and Mohammad, S. (2018). The impact of corporate social responsibility disclosure on financial performance: Evidence from the GCC Islamic banking sector. Journal of Business Ethics, 151(2), 451-471. 
[48] Porter, M. E., and Kramer, M. R. (2012). Shared Value: Die Brücke von Corporate Social Responsibility zu Corporate Strategy. In Corporate social responsibility (pp. 137-153). Springer, Berlin, Heidelberg.

[49] Reilly, A. H., and Larya, N. (2018). External communication about sustainability: Corporate social responsibility reports and social media activity. Environmental Communication, 12(5), 621-637.

[50] Ruisi, M. (2010). Antropologia ed etica aziendale. Note in tema di trascendentali e virtù imprenditoriali (Vol. 48). Giuffrè Editore, Milano.

[51] Rusconi, G. (2018). Business Ethics ed etica aziendale. Impresa ProgettoElectronic Journal of Management, (3).

[52] Shields, J. F., and Shelleman, J. M. (2017). A method to launch sustainability reporting in SMEs: The B Corp Impact Assessment framework. Journal of Strategic Innovation and Sustainability, 12(2), 10-19.

[53] Shields, J., and Shelleman, J. M. (2015). Integrating Sustainability into SME Strategy. Journal of Small Business Strategy, 25(2), 59-78.

[54] Spence, M. (2002). Signaling in retrospect and the informational structure of markets. American Economic Review, 92(3), 434-459.

[55] Stark, A. (1993). What's the Matter with Business Ethics? Harvard Business Review, 71(3), 38-40.

[56] Stiglitz, J. E. (2002). Information and the Change in the Paradigm in Economics. American economic review, 92(3), 460-501.

[57] Taj, S. A. (2016). Application of signaling theory in management research: Addressing major gaps in theory. European Management Journal, 34(4), 338348.

[58] Tarí, J. J., Molina-Azorín, J. F., and Heras, I. (2012). Benefits of the ISO 9001 and ISO 14001 standards: A literature review. Journal of Industrial Engineering and Management (JIEM), 5(2), 297-322.

[59] Tarquinio, L., and Posadas, S. C. (2020). La responsabilità sociale nelle piccole e medie imprese. «Conta quello che si fa non quello che si dice». Quaderni di ricerca sull'artigianato, $8(2), 249-272$.

[60] Todaro, N. M., Daddi, T., Testa, F., and Iraldo, F. (2020). Organization and management theories in environmental management systems research: A systematic literature review. Business Strategy \& Development, 3(1), 39-54.

[61] Wang, F., Lam, M., and Varshney, S. (2016). Corporate social responsibility: Motivation, pressures, and barriers. Journal of International Business Ethics, 9(1/2), 3 .

[62] Weber, O. (2017). Corporate Sustainability and Financial Performance of Chinese Banks. Sustainability Accounting, Management and Policy Journal, 8(3), 358-385.

[63] Wheelen, T. L., and Hunger, J. D. (2011). Concepts in strategic management and business policy. Pearson Education India.

[64] Wiesner, R., Chadee, D., and Best, P. (2018). Managing change toward environmental sustainability: A conceptual model in small and medium enterprises. Organization \& Environment, 31(2), 152-177. 
[65] Wright, P., and Ferris, S. P. (1997). Agency conflict and corporate strategy: The effect of divestment on corporate value. Strategic management journal, 18(1), 77-83.

[66] Wu, M. L. (2006). Corporate social performance, corporate financial performance, and firm size: A meta-analysis. Journal of American Academy of Business, 8(1), 163-171. 